\title{
Expression of Antimicrobial Peptides in Human Monocytic Cells and Neutrophils in Response to Dengue Virus Type 2
}

\author{
Jorge I. Castañeda-Sánchez ${ }^{\mathrm{a}}$ Diana Alhelí Domínguez-Martínez ${ }^{\mathrm{b}}$ \\ Nataly Olivar-Espinosa ${ }^{b}$ Blanca Estela García-Pérez ${ }^{c}$ María Alba Loroño-Pino ${ }^{d}$ \\ Julieta Luna-Herrerac ${ }^{c}$ Ma Isabel Salazar ${ }^{b}$ \\ a Departamento de Sistemas Biológicos, Universidad Autónoma Metropolitana, Unidad Xochimilco, Mexico City, \\ ${ }^{b}$ Laboratorio de Inmunología Celular e Inmunopatogénesis and ' Laboratorio de Inmunoquímica II, Departamento \\ de Inmunología, Escuela Nacional de Ciencias Biológicas-Instituto Politécnico Nacional, Mexico City, and \\ dLaboratorio de Arbovirología, Centro de Investigaciones Regionales 'Dr. Hideyo Noguchi', Universidad Autónoma \\ de Yucatán, Mérida, Mexico
}

\section{Key Words}

Dengue virus · hBD-1 · Cathelicidin LL-37 · hDEFAs •

$\beta$-Defensins

\begin{abstract}
Background/Aims: The innate immune response is remarkably important for controlling infections. Information about the participation of antimicrobial peptides (AMPs) in response to dengue virus (DENV) is scarce. The aim of this study was to examine the AMP response to DENV-2 in human THP-1 cells and neutrophils. Methods: Protein and mRNA levels of two AMPs - hBD-1 and cathelicidin LL-37 were assessed in DENV-infected macrophage-like THP-1 cells using qRT-PCR and indirect immunofluorescence. Also, mRNA levels of a-defensins (hDEFAs) and LL-37 were examined by qRT-PCR in human neutrophils taken from peripheral blood and treated with DENV-2. Results: mRNA expression of hBD-1 rose in THP-1 cells at 24-72 h, while protein expression increased later, from 48 to $72 \mathrm{~h}$ after infection. Cathelicidin LL-37 mRNA expression of DENV-infected THP-1 cells was observed at 6-48 h after infection, while protein levels increased importantly up to $72 \mathrm{~h}$ after infection. Re-
\end{abstract}

\section{KARGER}

E-Mail karger@karger.com www.karger.com/int garding neutrophils, the mRNA expression of hDEFAs and LL-37 increased slightly at 2 and $5 \mathrm{~h}$ after the contact with DENV-2. Conclusion: THP-1 cells and human neutrophils strongly respond to DENV by producing AMPs: hBD-1 and LL-37 for the THP-1 cells and hDEFAs and LL-37 for neutrophils. However, the direct effect of these molecules on DENV particles remains unclear.

(c) 2016 S. Karger AG, Basel

\section{Introduction}

Dengue, caused by the dengue virus (DENV), represents an increasingly grave global health problem. Of the estimated 390 million infections every year, 50-100 million are symptomatic [1]. The innate immune response, including the production of interferons, complement, and antimicrobial peptides (AMPs), might be crucial to control the disease. However, the direct antimicrobial activity and the immunomodulatory role of these AMPs have not yet been established in cell types that are crucial for innate immune response in viral infections, such as monocytes and neutrophils.

Ma Isabel Salazar, Laboratorio de Inmunología Celular e Inmunopatogénesis Departamento de Inmunología, Escuela Nacional de Ciencias Biológicas Instituto Politécnico Nacional, Prolong. Manuel M. Carpio y Plan de Ayala S/N Col. Santo Tomás, D.F., CP 11340 (Mexico)

E-Mail isalazarsan@yahoo.com 
AMPs are small polypeptides with low molecular weight and a broad spectrum of antimicrobial activity [2] . These peptides are produced by a large number of cells from different species all along the phylogenetic scale [3]. As part of the innate immune response, their antimicrobial activity targets bacteria (Gram-negative and Grampositive), fungi, and viruses. These evolutionarily conserved molecules are not only key defense elements of immunity, but also participate in other relevant activities such as immunomodulation, chemotaxis, induction of angiogenesis, and wound healing $[2,3]$.

Cathelicidins and defensins are the two major families of AMPs in mammals. They contribute to the antimicrobial innate immune response by disrupting the cell membranes of pathogens [4]. Due to their cationic nature, defensins and cathelicidins interact with negatively charged phospholipids present in the lipid bilayers of different pathogens, including enveloped viruses $[5,6]$.

Defensins are cationic peptides ranging from 18 to 45 amino acids $(2-6 \mathrm{kDa})$ with $\beta$-sheet structures stabilized by disulfide bonds. Six $\alpha$-defensins and $31 \beta$-defensins are expressed in humans. The $\alpha$-defensins (hDEFAs) are abundantly found in human neutrophil granules (HNP-1 to -4), although they are also present in Paneth cells (HD5 and -6) [7]. A recent study reported that HNP-1 to -4 are expressed by monocytes/macrophages, immature dendritic cells, NK cells, B cells, and $\gamma \delta$-T cells after stimuli with cytokines [6]. HNP-1 to -3, HD-5, and HBD-3 are also lectins that bind to glycolipids and glycoproteins present on the pathogen cell surface [6].

In contrast, $\beta$-defensins (hBDs) are produced in a wide variety of tissues, including the epithelium, skin, and mucosa $[6,8]$, and participate in protection [9]. The production of hBD-1 occurs after the exposure of monocytes and plasmacytoid dendritic cells to lipopolysaccharide (LPS) [10]. In addition to their antimicrobial activity, $\alpha$ - and $\beta$-defensins can recruit monocytes, immature dendritic cells, and T cells to infection sites $[11,12]$, as well as exhibit antiviral activity against enveloped and nonenveloped viruses $[6,13]$.

Cathelicidins encompass about 30 of the found AMPs in mammals. One cathelicidin gene, denominated LL-37, is reportedly unique to humans [5]. LL-37 is found in neutrophil granules as a propeptide that is released only after processing by neutrophil elastase [14]. This cathelicidin is known to attract neutrophils, monocytes, mast cells, and T cells, modify the transcriptional response in macrophages, and participate in vascularization and reepithelialization [15]. During injury and inflammation, LL-37 is produced not only by neutrophils, but also by

AMPs in Response to DENV mast cells, lymphocytes, and keratinocytes [2]. Importantly, this AMP has recently been implicated in the defense against an influenza virus in a dose-dependentmanner [16].

The aim of the present study was to examine the expression of AMPs in two cell types, macrophage-like THP-1 cells, and neutrophils that actively participate in the immune response to DENV. Clear evidence exists about the significant overproduction of hBD-1 in sera from humans infected with DENV [17]. However, both the essential cell types participating in this process of infection and the final effect of this defensin on virus infectivity remain unclear. Additionally, the inhibition of DENV infection in Aedes aegypti mosquitoes induced by the symbiont Wolbachia appears attributable to insect defensins [18].

We herein assessed the expression hBD-1 and cathelicidin LL-37 in THP-1 monocytic cells, as well as the production of hDEFAs and LL-37 in human neutrophils in response to DENV-2. The expression of hBD-1 was determined at both mRNA and protein levels in human macrophage-like THP- 1 cells after DENV infection, and increased expression of mRNA from 24 to $72 \mathrm{~h}$ and a significant amount of protein from 48 to $72 \mathrm{~h}$ were observed. THP- 1 cells also increased mRNA expression and protein intracellular levels for LL-37 from 6 to $72 \mathrm{~h}$. Meanwhile, in neutrophils the expression of mRNAs coding for hDEFAs and LL-37 increased significantly at 2 and $5 \mathrm{~h}$ in response to DENV-2.

\section{Materials and Methods}

\section{Virus Propagation}

DENV strains were kindly donated to our lab by the Laboratory of Arbovirology at the 'Centro de Investigaciones Regionales Dr. Hideyo Noguchi' at the Universidad Autónoma de Yucatán in Mexico. Viruses were obtained with informed consent from patients, according to the protocol of the Bioethics Committee at that institution and the Ethics Commission of the Escuela Nacional de Ciencias Biológicas. The virus strains herein tested were: DENV-2 YUC17438 and DENV-2 YUC18500 (both from the American/ Asian genotype and from the same outbreak); each section and figure specifies the strain used in the specific assay. For virus propagation, C6/36 cells were grown to confluence at $28^{\circ} \mathrm{C}$ in Leibovitz's L-15 medium (Sigma-Aldrich Co., St. Louis, Mo., USA) supplemented with $8 \%$ FBS (PAA, Canada). We infected the cells in T-25 culture flasks and incubated them for 7 days at $28^{\circ} \mathrm{C}$. The L-15 medium was replaced at day 7 and infected cells continued to be incubated until day 12 , when supernatants were collected, and $250 \mu \mathrm{l}$ aliquots were stored at $-70^{\circ} \mathrm{C}$ to await further use. Supernatants from uninfected C6/36 cells were also collected at the same time point and used to treat our mock controls throughout the experiments. 
Titrations of virus stocks were carried out in $90-100 \%$ confluent monolayers of C6/36 through immunohistochemistry assays. Briefly, serial dilutions of stocks were performed and interaction with cell monolayers in 24-well plates was allowed for $1 \mathrm{~h}$. Cells were rinsed twice, then $1 \mathrm{ml}$ of overlay medium containing 1\% carboxymethyl cellulose was placed in each well. Cells were incubated at $28^{\circ} \mathrm{C}$ for 6 days, the overlay carefully removed, and cells fixed with a cold mix of $30 \%$ acetone-PBS. For immunostaining we used 4G2 (clone D1-4G2-4-15) monoclonal antibody (Millipore, Darmstadt, Germany) and a secondary anti-mouse IgG coupled to HRP (Invitrogen, Frederick, Md., USA). To reveal infection foci on cells, 3,3'-diaminobencidine liquid substrate system (SigmaAldrich Co., St. Louis, Mo., USA) was used (online suppl. fig. 1; see www.karger.com/doi/10.1159/000446282 for all online suppl. material).

\section{Cell Cultures and DENV Treatment}

In this study we used cell line cultures (THP-1 cells, ATCC ${ }^{\circledR}$ TIB-202 ${ }^{\mathrm{TM}}$ ) as well as cells obtained from peripheral blood samples. THP-1 cells were obtained from a promonocytic cell line derived from an infant with acute monocytic leukemia. These cells exhibit a promonocytic phenotype, grow in suspension, and express $\mathrm{Fc}$ and $\mathrm{C} 3 \mathrm{~b}$ receptors on the cell surface. First, THP-1 cells were allowed to grow for 1 week in suspension in RPMI medium (Sigma-Aldrich Co.) supplemented with 10\% FBS (PAA).

Prior to infection with DENV, THP-1 cells were differentiated to monocyte-derived macrophages with a treatment that encompasses exposure to phorbol-12-myristate-13-acetate $(\mathrm{PMA} ;=1$ $\mu \mathrm{g} / \mathrm{ml}$ per $1 \times 10^{6}$ cells, Sigma-Aldrich) [19]. The reported protocol was modified according to our results; the final conditions were $72 \mathrm{~h}$ of PMA treatment followed by a 5-day resting period $\left(37^{\circ} \mathrm{C} ; 5 \% \mathrm{CO}_{2}\right.$ atmosphere). According to our data, this treatment caused cells to become adherent and develop macrophagic characteristics at the morphological level and functionally to be more responsive, producing reactive oxygen species (ROS) (online suppl. fig. 2). According to the literature, this phenotype shows an increased expression of CD14 [19], which probably make them more susceptible to DENV infection. All the cells used in these studies where differentiated with PMA. After treatment with PMA and incubation, cells were replenished with fresh media and after 3 more days were infected with DENV. Then $3 \times 10^{6}$ cells were placed in a culture plate and the course of infection was assessed using anti-NS1 (Clone DN3, Abcam) and anti-E clone 3H5-1 (Millipore) antibodies in indirect immunofluorescence and flow cytometry assays at 24,48 , and $72 \mathrm{~h}$ after the infection with DENV-2.

Briefly, for immunofluorescence assays, THP-1 cell monolayers from each time point were fixed with $4 \%$ paraformaldehyde and $3 \mathrm{H} 5$ antibody was used as a primary antibody and a goat anti-mouse IgG antibody coupled with FITC was used as a secondary antibody (Invitrogen). Cells were covered with Vectashield (Vector Laboratories Inc., Burlingame, Calif., USA) and slides observed in a Nikon fluorescence microscope. For flow cytometry assays, THP-1 cells were carefully detached from the plate surface using a cell scraper and fixed with $2 \%$ paraformaldehyde; $1 \%$ BSA in PBS was used to block for $1 \mathrm{~h}$ and then permeabilized using $0.1 \%$ Triton X-100. As a primary antibody anti-NS1 (clone DN3) was used as it was an IgG1 antibody, an irrelevant IgG1 antibody was used as an isotype control. A secondary antibody goat anti-mouse IgG coupled to FITC (Invitrogen). Cytometry data was captured in a FACScalibur.
Neutrophils were obtained from the peripheral blood of healthy volunteer donors using Vacutainer ${ }^{\circledR}$ (BectonDickinson, San Jose, Calif., USA) tubes with EDTA; volunteers signed an informed consent to participate in the protocol approved by the Ethics Commission of the Escuela Nacional de Ciencias Biológicas. To separate cells, $5 \mathrm{ml}$ of total blood was stratified on $5 \mathrm{ml}$ of Polymorphprep ${ }^{\mathrm{TM}}$ (Axis-Shield PoC AS, Oslo, Norway), and neutrophils were obtained by gradient according to the manufacturer's protocol. From the polymorphonuclear band, cultures were prepared by placing 2 $\times 10^{6}$ cells in each well of 6 -well plates. After adhering to the plate surface, neutrophils were treated with each of the DENV serotypes separately at an MOI of 1 . A mock group was included for each cell type as the negative control. Cultures were maintained with RPMI (Sigma-Aldrich Co.) containing $10 \% \mathrm{FBS}$ (PAA, Canada) at $37^{\circ} \mathrm{C}$ in a $5 \% \mathrm{CO}_{2}$ atmosphere, and were collected after 2 and $5 \mathrm{~h}$ for the hDEFA analysis by RT-PCR.

The differentiated THP-1 cells were divided into three groups: the untreated control, the DENV-2 treatment, and the LPS treatment $(100 \mathrm{ng} / \mathrm{ml}$; the positive control). The confluent monolayers of THP-1 cells were infected with the previously reported DENV2 YUC18500 strain [20] at an MOI of 1 . Once treated, cultures were incubated at $37^{\circ} \mathrm{C}$ in a $5 \% \mathrm{CO}_{2}$ atmosphere and cells from each group were collected at $6,12,24,48$, and $72 \mathrm{~h}$ after treatment. Since neutrophils are short-lived [21] and there is no evidence that they become infected with DENV, we used short exposure times (2 and $5 \mathrm{~h})$ for each of the DENV-2 YUC17438 treatments $(\mathrm{MOI}=1)$ to examine hDEFA and LL-37 mRNA responses.

For the qRT-PCR assays, the medium was removed from each well and $500 \mu$ of TRIzol $^{\circledR}$ (Invitrogen) was added. Cells were collected from each well in an Eppendorf tube, centrifuged, and stored at $-70^{\circ} \mathrm{C}$ to await RNA extraction. For the microscopy assays, a pretreated and sterilized glass coverslip was introduced into each of the wells prior to culturing the THP-1 cells. At each point in time, coverslips were carefully removed from the culture plate, washed 3 times with PBS, and fixed at room temperature with $4 \%$ paraformaldehyde for $1 \mathrm{~h}$. Then coverslips were stored at $4^{\circ} \mathrm{C}$ in PBS and the immunofluorescence staining was subsequently performed to detect hBD-1 and LL-37.

\section{NBT Assay to Assess THP-1 Cells and Neutrophil Activation in} the Presence of DENV

To determine DENV-mediated cellular activation in cells, an NBT (nitro blue tetrazolium) reduction assay was conducted to detect ROS. All assays were carried out in duplicate. Briefly, neutrophils were adjusted to a cell density of $5 \times 10^{6}$ cells $/ \mathrm{ml}$ in glucose-PBS and $100 \mu \mathrm{l}$ were placed in each well of a 96-well plate. First, neutrophils were separated and allowed to bind to the plate surface for $30 \mathrm{~min}$; meanwhile, THP-1 cells were differentiated with PMA as previously described before the experiment. Then each assay was carried out in triplicate for the following treatments: basal (without treatment), PMA $(1 \mu \mathrm{g} / \mathrm{ml})$, and DENV-2 at an MOI of 1 for each cell type.

To establish whether or not the treatment with DENV had any effect on activation and ROS formation, we incubated neutrophils for each experimental group at $37^{\circ} \mathrm{C}$ for either 2 or $5 \mathrm{~h}$, or THP-1 cells for 24 and $48 \mathrm{~h}$ in a $5 \% \mathrm{CO}_{2}$ atmosphere. Immediately after the corresponding incubation time, glucose-PBS was replaced by $40 \mu \mathrm{l}$ of $0.2 \%$ NBT (Sigma) prepared in saline solution and cells were incubated for another $30 \mathrm{~min}$. The solution was removed and replaced by $200 \mu$ l of lysis solution $(0.08 \mathrm{~N} \mathrm{NaOH}$ dissolved in $10 \%$
10

Intervirology 2016;59:8-19

DOI: $10.1159 / 000446282$
Castañeda-Sánchez et al. 
Table 1. Specific primers used for qRT-PCR analysis of AMPs in monocytes and neutrophils

\begin{tabular}{|c|c|c|c|}
\hline $\begin{array}{l}\text { Transcript } \\
\text { analyzed }\end{array}$ & Primer sequence & $\begin{array}{l}\text { Primer } \\
\text { length, } \mathrm{nt}\end{array}$ & $\begin{array}{l}\text { Amplicon } \\
\text { length, bp }\end{array}$ \\
\hline hBD-1 & $\begin{array}{l}5^{\prime} \text { TGTCTGAGATGGCCTCAGGT } 3^{\prime} \text { forward } \\
5^{\prime} \text { CAGGTGCCTTTGAATTTTGGT } 3^{\prime} \text { reverse }\end{array}$ & $\begin{array}{l}20 \\
21\end{array}$ & 133 \\
\hline LL-37 & $\begin{array}{l}5^{\prime} \text { TCGGATGCTAACCTCTACCG } 3^{\prime} \text { forward } \\
5^{\prime} \text { ACAGGCTTTGGCGTGTCT } 3^{\prime} \text { reverse }\end{array}$ & $\begin{array}{l}20 \\
18\end{array}$ & 233 \\
\hline hDEFA-1 & $\begin{array}{l}5^{\prime} \text { GAGGAGCCAGCCTGGATTTAT } 3^{\prime} \text { forward } \\
5^{\prime} \text { TTCGAGCAACCTTGAGACCA } 3^{\prime} \text { reverse }\end{array}$ & $\begin{array}{l}21 \\
20\end{array}$ & 125 \\
\hline $\begin{array}{l}\text { hDEFA-1 to }-3 \\
\text { (pool) }\end{array}$ & $\begin{array}{l}5^{\prime} \text { TCCTTGCTGCCATTCTCCTG 3' forward } \\
5^{\prime} \text { TGAGCCTGGATGCTTTGGAG 3' reverse }\end{array}$ & $\begin{array}{l}20 \\
20\end{array}$ & 164 \\
\hline hDEFA-4 & $\begin{array}{l}5^{\prime} \text { ACTGCCTCATTGGTGGTGTG } 3^{\prime} \text { forward } \\
5^{\prime} \text { GGCGTTCCCAGCATGACATT } 3^{\prime} \text { reverse }\end{array}$ & $\begin{array}{l}20 \\
20\end{array}$ & 91 \\
\hline hACTB & $\begin{array}{l}5^{\prime} \text { CCAACCGCGAGAAGATGA } 3^{\prime} \text { forward } \\
5^{\prime} \text { TCCATCACGATGCCAGTG } 3^{\prime} \text { reverse }\end{array}$ & $\begin{array}{l}18 \\
18\end{array}$ & 121 \\
\hline
\end{tabular}

SDS) and homogenization was carried out gently. Finally, absorbance values at $600 \mathrm{~nm}\left(\mathrm{OD}_{600 \mathrm{~nm}}\right)$ were obtained in an ELISA plate reader and results graphed. This cell disruption method was standardized as an optimization to the initial protocol reported to quantify superoxide anion production in phagocytic cells [22].

RNA Extraction, cDNA Synthesis, and Amplicons

Total RNA extraction was carried out with Trizol according to the manufacturer's instructions. After extracting and resuspending the total RNAs $(40 \mu \mathrm{l})$, they were treated with $1 \mathrm{U} / \mu \mathrm{l}$ DNase-I (Invitrogen) at room temperature for $15 \mathrm{~min}$ before being precipitated with isopropanol. For reverse transcription (RT), the RNA was quantified in a Nanodrop (Thermo Scientific, Redwood City, Calif., USA) and then $3 \mu \mathrm{g}$ of total RNA were added with $0.5 \mu \mathrm{g}$ of oligo-dT (Invitrogen) and incubated for $10 \mathrm{~min}$ at $70^{\circ} \mathrm{C}$. The RT reaction included the following: $1 \times$ single strand buffer, DDT $(0.5$ $\mathrm{mM}$ ), $500 \mathrm{mM}$ of each deoxynucleotide triphosphate (Invitrogen), and MML-V reverse transcriptase (200 U, Invitrogen). Each RT reaction was incubated for $1 \mathrm{~h}$ at $42{ }^{\circ} \mathrm{C}$ to obtain cDNA. The PCR was performed using each cDNA and a commercial master mix with $1.5 \mathrm{mM} \mathrm{MgCl}_{2}$ (Qiagen).

The $\beta$-actin gene (hACTB) was used as the endogenous control. The primers used for the RT-PCR of the AMPs (with exception of the hDEFAs) have been characterized elsewhere [23]. The corresponding sizes for amplicons were for hACTB (121 bp), hBD1 (133 bp), LL-37 (251 bp), hDEFA-1 (125 bp), hDEFA-1 to -3 pool (164 bp), and hDEFA-4 (91 bp). All the primers that were used are listed in table 1.

Quantitative Real-Time PCR and Data Analysis

The corresponding amplicons were obtained with synthesized cDNAs by qPCR reactions starting with $2 \mathrm{~min}$ at $50^{\circ} \mathrm{C}$ followed by 5 min of initial denaturation time at $95^{\circ} \mathrm{C}$. Denaturation was followed by 40 cycles of: $15 \mathrm{~s}$ of denaturation at $95^{\circ} \mathrm{C}, 15 \mathrm{~s}$ of annealing at $60^{\circ} \mathrm{C}$, and $15 \mathrm{~s}$ of elongation at $72^{\circ} \mathrm{C}$. After all the cycles, 5 min of final elongation at $72^{\circ} \mathrm{C}$ was allowed. EvaGreen (Biotium) and ROX reference dye (Invitrogen) were used for reactions, which were run in a Step One Plus Thermocycler (Applied Biosystems). The analysis was performed with ddCt using hACTB to nor-

AMPs in Response to DENV malize data. The relative expression was calculated in relation to the mock-infected control using Step One V2.3 software.

Detection of $h B D-1$ and LL-37 by Immunofluorescence Assays

The cells fixed on the coverslip were permeabilized by incubating them with $0.2 \%$ Triton X-100 in PBS for 15 min. The coverslips were washed twice with Hank's balanced salt solution (HBSS) and blocked using BSA (5\%) in PBS. To detect the presence of defensin $\mathrm{hBD}-1$ and cathelicidin LL-37, cells were incubated for $2 \mathrm{~h}$ at $37^{\circ} \mathrm{C}$ with specific polyclonal antibodies for hBD-1 and LL-37 (Santa Cruz Biotechnology, Santa Cruz, Calif., USA). The cells were washed 5 times with HBSS. The secondary antibody conjugated to FITC was added and incubated for $90 \mathrm{~min}$ at $37^{\circ} \mathrm{C}$, and then it was removed and slides were washed 5 times with HBSS. Finally, the stained preparations were mounted on slides using VectashieldDAPI (Vector Laboratories) and examined with a confocal scanning system attached to an inverted microscope (LSM5, Pascal; Zeiss, Oberkochen, Germany).

\section{Statistical Analysis}

The data for each experimental group are presented as means \pm SD. For statistical significance, the numerical data were analyzed using a two-way ANOVA test with GraphPad Prism software, version 5.0. A p value $<0.05$ was considered as statistically significant.

\section{Results}

\section{Defensin hBD-1 Was Produced Early in Response to DENV in THP-1 Cells}

To examine the expression level of mRNA coding for hBD-1 in the macrophage-like THP-1 cells treated with DENV-2 YUC18500, we performed qRT-PCR and indirect immunofluorescence assays. For cells treated with DENV-2 YUC18500 or LPS (positive control), as well as for the negative control, values were determined at 6, 12,

Intervirology 2016;59:8-19 
24,48 and $72 \mathrm{~h}$ (fig. 1). Assays were also conducted to determine the expression levels of $\mathrm{hBD}-2$ and $\mathrm{hBD}-3$, but found no detectable levels in THP-1 cells under the current protocol.

The analysis of hBD-1 mRNA by qRT-PCR showed a significant increase, compared to the negative control in the normalized expression levels at 24 and $48 \mathrm{~h}$ after treatment with DENV-2 YUC18500, similar to the LPS-positive control level at the same time frames (fig. 1). A greater increase was found for the DENV-2 YUC18500 group at $72 \mathrm{~h}(\mathrm{p}<0.05)$.

In indirect immunofluorescence assays, we observed an important presence of hBD-1 polypeptide after the treatment of THP-1 cells with DENV-2 YUC18500 and YUC17438, obtaining similar results with both viruses. Production of hBD-1 was evident at 48 and $72 \mathrm{~h}$, when cells stained with the specific antibody anti-hBD-1-FITC showed a clear fluorescent signal (fig. 2; online suppl. fig. 3). This defensin was detected at the earliest tested time point $(6 \mathrm{~h})$ in the LPS-positive control.

To establish the corresponding infection levels, we examined intracellular NS1 and E viral proteins levels in treated macrophage-like THP-1 cells (fig. 3; online suppl. fig. 3). A consistent increment was observed in the NS1 protein from $24 \mathrm{~h}$ to the last assayed time of $72 \mathrm{~h}$, evidenced by both flow cytometry and indirect immunofluorescence. According to the flow cytometry data for the NS1 protein, $14 \pm 3 \%$ of the THP- 1 cells showed infection at $24 \mathrm{~h}$ and up to $25 \pm 4 \%$ showed infection at $72 \mathrm{~h}$. The NS1 virus protein signal was clearly observed in immunofluorescence analysis in a few cells after $24 \mathrm{~h}$.

The E protein signal in THP-1 in immunofluorescence was observed mostly at 48 and $72 \mathrm{~h}$, although a slight signal was also detected $24 \mathrm{~h}$ after treatment with DENV-2. In addition, THP-1 cells clearly responded to DENV-2 stimuli by producing ROS as the NBT assay showed (online suppl. fig. 2).

\section{THP-1 Cell Infection and hBD-1 Production after} $3 d p i$

The expression and production of hBD-1 in THP-1 cells was also examined for a longer period of time: at 3 , 5 , and 8 days after infection with DENV-2 YUC18500 with 3 used as a reference value. Production of hBD-1 was not found above $3 \mathrm{dpi}$, and there were no significant differences in hBD-1 levels between the control and DENVtreated cells: neither when using RT-PCR, nor in the immunofluorescence assays (online suppl. fig. 4). It is noteworthy that low basal production of the hBD-1 polypeptide occurred in all control groups.

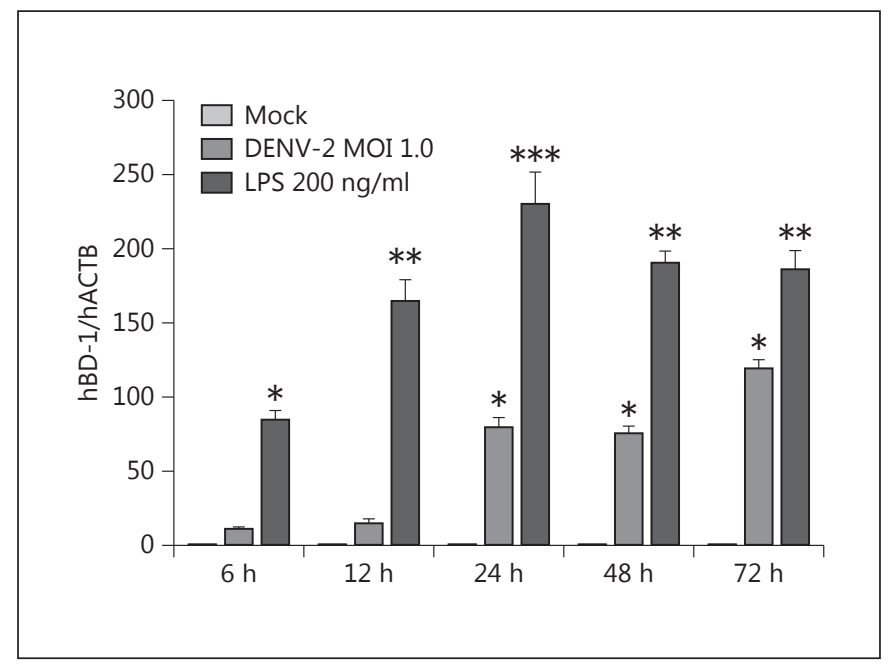

Fig. 1. Kinetics of hBD-1 mRNA expression in THP-1 macrophage-like cells infected with DENV-2 YUC18500. In three independent experiments, THP-1 cells were treated with DENV-2 at an MOI of 1, followed by RNA extraction, cDNA synthesis, and qRT-PCR analysis. The qPCR reactions were carried out for hBD1 and internal gene hACTB in duplicate in each experiment. The resulting values were normalized to the expression levels of the internal gene (hACTB), and relative expression using a mock value as a reference is shown in the graph. Treatment with LPS (100 $\mathrm{ng} / \mathrm{ml}$ ) was used as the positive control in this time course. Values for mock-infected cells were considered as the basal value of expression for comparison; means \pm SD are shown for each time point. Statistical significance for ANOVA test: ${ }^{*} \mathrm{p}<0.05$; ${ }^{*} \mathrm{p}<$ $0.01 ;{ }^{* * *} \mathrm{p}<0.001$.

Infection in THP-1 macrophage-like cells with DENV was verified by evaluating expression of the envelope (E) viral proteins and also the NS1 protein by flow cytometry protein at 24,48 , and $72 \mathrm{~h}$ as previously described (fig. 3).

\section{Cathelicidin LL-37 Production in THP-1 Cells after DENV-2 Infection}

To establish whether or not THP-1 macrophage-like cells responded to the DENV-2 stimuli by producing an AMP other than hBD-1, we proceeded to test the production of cathelicidin LL-37 at the same points in time. LL37 mRNA expression was examined by qRT-PCR at 6,12 , $24,48$, and $72 \mathrm{~h}$ (fig. 4). A significant difference ( $\mathrm{p}<0.05)$ was observed between the mock control and the treatment with DENV-2 YUC18500 starting $6 \mathrm{~h}$ after infection, and this difference clearly declined at $72 \mathrm{~h}$. No other differences between treated and mock control groups were observed later (data not shown). Confocal micros- 


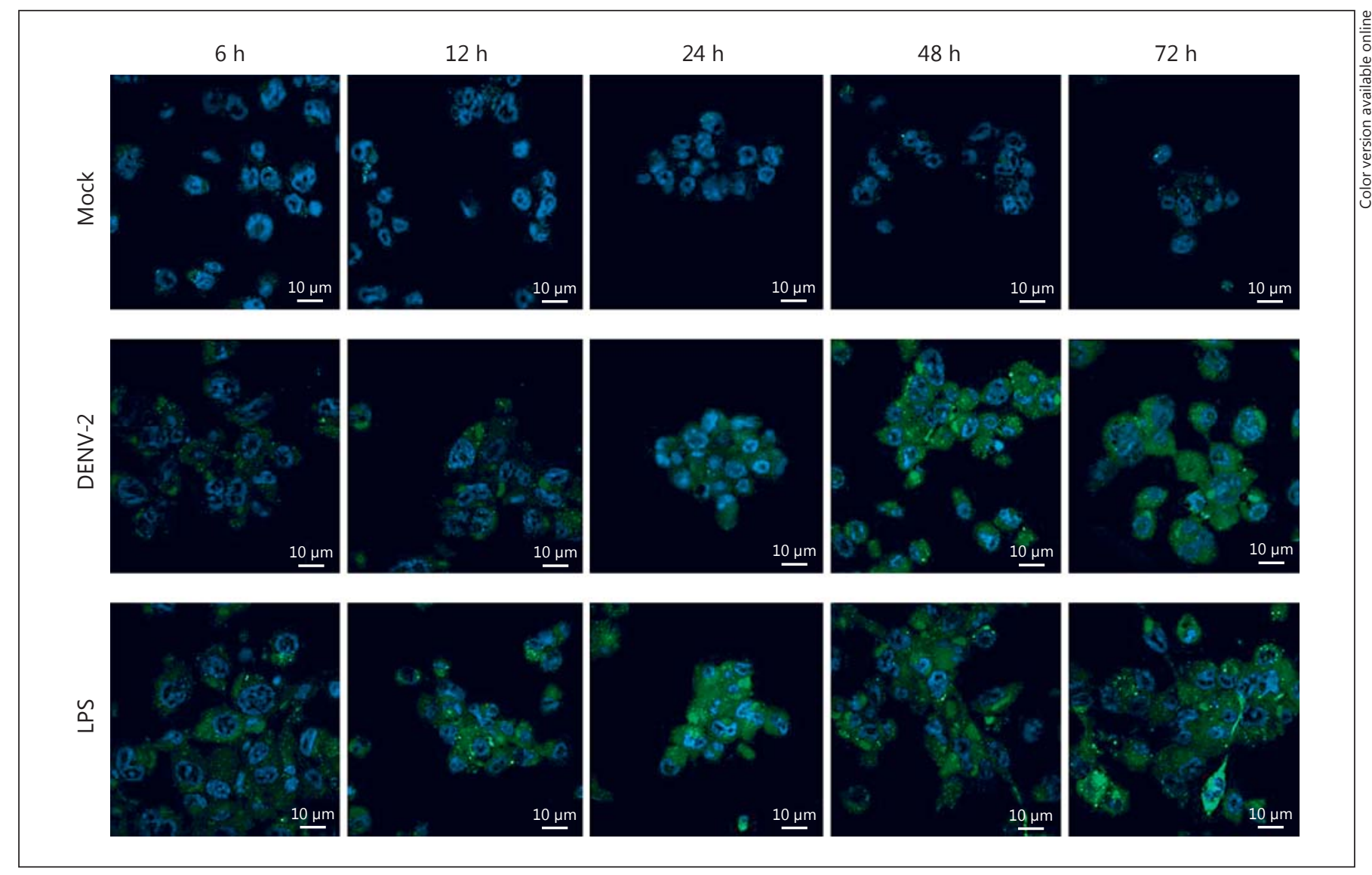

Fig. 2. DENV-2 stimulated production of hBD-1 peptide in THP1 macrophage-like cells. Each time course analysis was based on three experimental groups of THP-1 cells: mock-infected, DENVYUC18500-infected (MOI = 1), and LPS-treated (100 ng/ml) cells. The hBD-1 peptide was measured intracellularly in THP-1 cells; one representative assay is shown for the experiment performed in triplicate. Specific monoclonal antibodies against hBD-1 were used for indirect immunofluorescence assays. The slides were analyzed by confocal microscopy. Nuclei are observed in blue due to staining with DAPI, while the hBD-1 signal is observed in green due to the secondary antibodies coupled to FITC (colors in online version only). Representative fields are observed at $\times 400$. copy assays carried out at the same time points showed the LL-37 signal in both DENV-infected cells and the LPS control at all tested time points (fig. 5).

\section{Human Neutrophil Production of hDEFAs in Response to DENV-2}

Although neutrophils are the most important producers of hDEFAs [24], it has not been established whether or not these cells are infected by DENV. Therefore, an NBT assay was carried out to measure cellular activation in the presence of the virus, and PMA $(1 \mu \mathrm{g} / \mathrm{ml})$ was used as the control for neutrophil activation (online suppl. fig. 5). Compared to the negative control, a greater production of ROS was observed after the exposure of neutrophils to DENV-2, which was comparable to the values found with exposure of these cells to LPS. The LPS control showed $1.1 \pm 0.1$ units at $\mathrm{OD}_{600 \mathrm{~nm}}$, DENV-2 YUC17438exposed cells from 0.8 to 1.2 units, and the basal control showed $0.15 \pm 0.05$ units in each case at $\mathrm{OD}_{600 \mathrm{~nm}}$.

We proceeded to challenge the neutrophils with DENV-2 to establish whether or not a differential expression of mRNAs for DEFAs existed. Since the life span of these cells is short [21], we examined only early time points ( 2 and $5 \mathrm{~h}$ ); we found differences in all examined mRNAs for hDEFAs in the presence of DENV-2 at 2 and $5 \mathrm{~h}$. Finally, qRT-PCR experiments performed in duplicate showed significant differences in the mRNAs for all the examined hDEFAs (-1, pool -1 to -3 , and -4$)$ and cathelicidin LL-37 in DENV-2 YUC17438-treated neutrophils (fig. 6). 

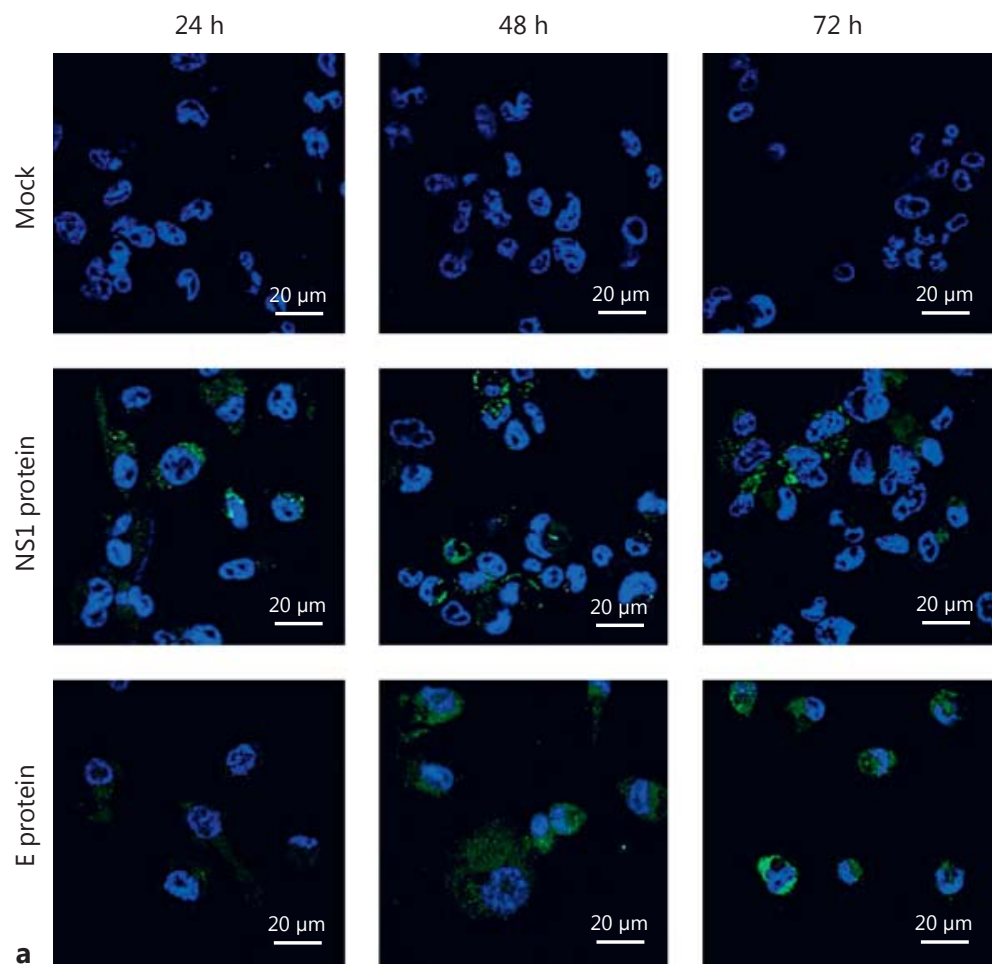

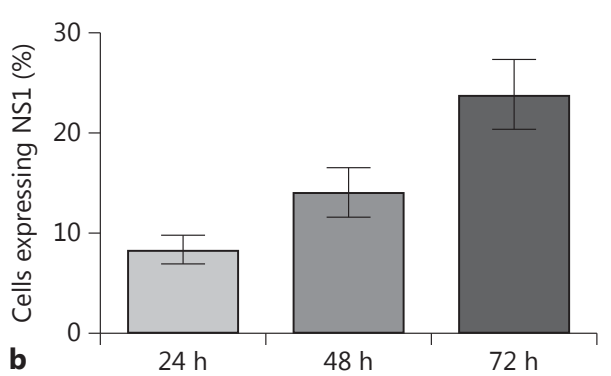

b

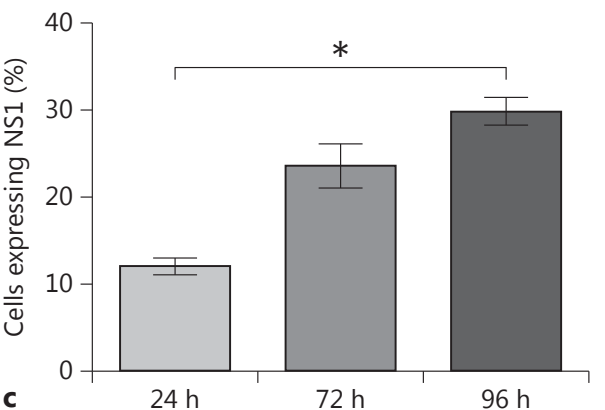

Fig. 3. Expression of the NS1 and E virus protein in DENV-2infected THP-1 cells. a DENV-2 YUC18500 infection of THP-1 macrophage-like cells was examined at different time points by indirect immunofluorescence to detect the NS1 and E viral proteins. b Immunofluorescence data obtained for NS1 were analyzed by LSM software to estimate the percentage of positive cells. c Percentage of THP-1 cells positive for the NS1 protein were also quantified by flow cytometry. Mock-infected cells were used as the negative control. Infection was very clear at $72 \mathrm{~h}$, although the E signal was detected at earlier times $(24$ and $48 \mathrm{~h}) .{ }^{*} \mathrm{p}<0.05$.
Fig. 4. DENV-2 stimulated the expression of cathelicidin LL-37 transcript in human THP-1 cells. THP-1 macrophage-like cell monolayers were infected with DENV-2 YUC18500. LL-37 mRNA levels were analyzed at $6,12,24,48$, and $72 \mathrm{~h}$ after infection. The LL-37 data were normalized to the levels of expression of the internal gene hACTB. Relative expression in comparison with mock controls is shown. Significant differences from mock-infected cells were found up to $48 \mathrm{~h}$ after infection $\left({ }^{*} \mathrm{p}<0.05\right.$; $\left.{ }^{* *} \mathrm{p}<0.001\right)$.

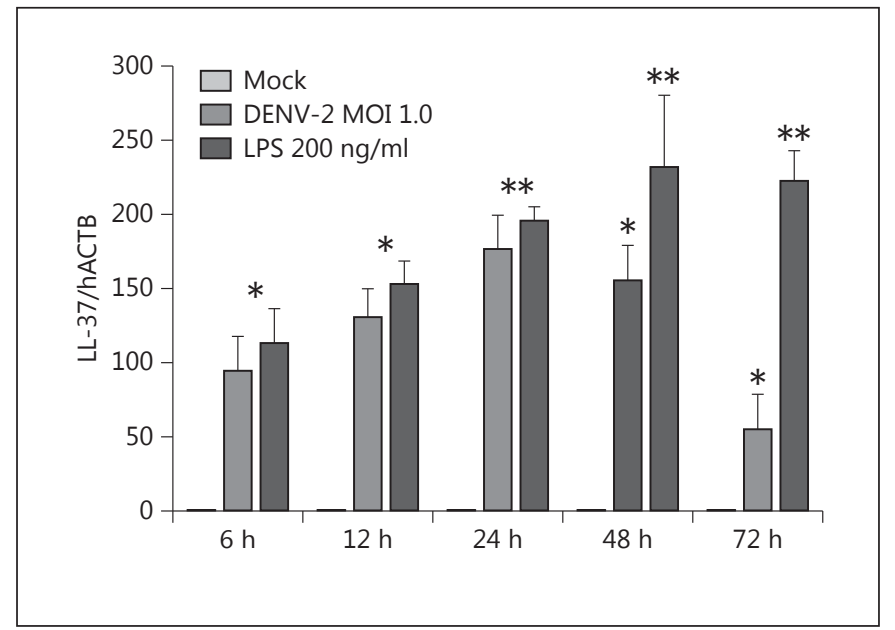




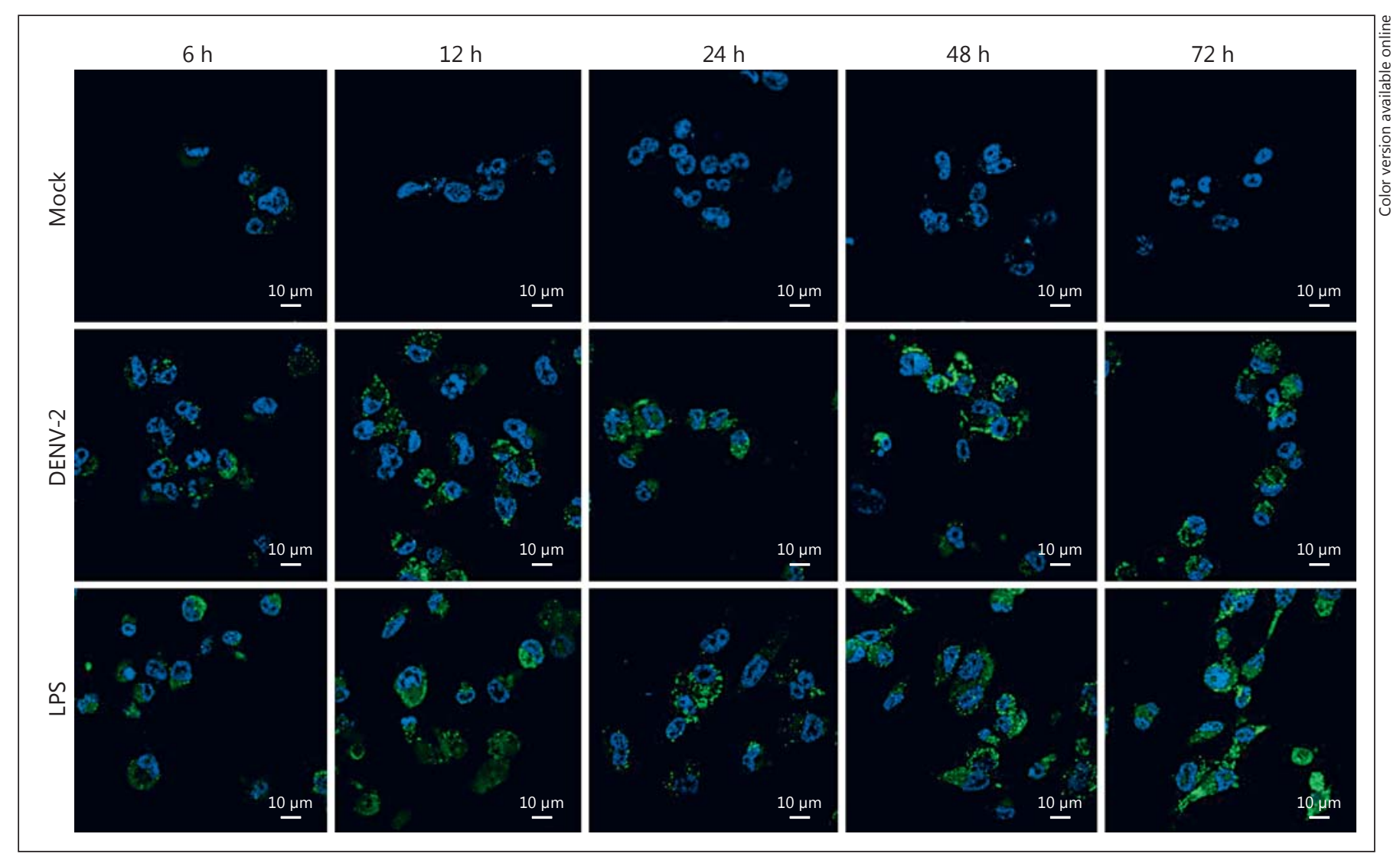

Fig. 5. DENV-2 also stimulated the production of cathelicidin LL-37 peptide in human THP-1 cells. Production of LL-37 intracellular peptide in macrophage-like THP-1 cells was examined using a specific antibody against this AMP and secondary antibody conjugated to FITC. LL-37 production was observed all along this time course in both DENV-2 YUC18500-infected and LPS-treated THP-1 cells, as shown in the pictures taken by confocal microcopy.

\section{Discussion}

AMPs are one of the primary mechanisms used by the innate immune defense against invading microorganisms, including viruses. It has been proven that these molecules target both enveloped RNA and DNA viruses $[25,26]$. In both cases, the action mechanism of direct AMP activity involves pore formation, membrane disruption, and ion efflux. At the level of permeation, the AMP peptide sequence might involve a combination of AMPs. Other important factors are lipid composition in the targeted membrane and AMP concentration [27]. AMPs can act on pathogens at the extracellular milieu and in different cellular compartments, such as the phagolysosome [28]. In addition to their direct activity on pathogens, AMPs also play an important role in modulating the immune response $[3,29]$. Although AMPs are known to be helpful in controlling viral infections, their function in regard to infection by DENV remains poorly understood.

Cells and tissues involved in the immune defense against pathogens are classic producers of AMPs. Defensins, for example, are found at their highest levels in the granules of neutrophils and macrophages, and these peptides are also released by leukocytes [30-33]. It is clear that defensins participate in lessening the effects of some viral infections, including RSV, HIV, IAV, and HPV [6, 33]. Defensin-inhibiting activity occurs mostly at the viral entry step, although effects at other stages of infection have also been described [6]. Initially reported as herpes simplex virus type 1 neutralizers [30], hDEFAs were later found to inhibit infection of macrophages by HIV through the upregulation of CC-chemokines [33]. Besides $\alpha$-defensins, human cathelicidin LL-37 also shows an effective 
Fig. 6. Expression of hDEFAs and cathelicidin LL-37 transcripts in human neutrophils treated with DENV-2 YUC17438. The expression levels of mRNAs for hDEFA-1 (a), hDEFA-4 (b), a pool of hDEFA-1 to -3 (c), and LL-37 (d) were examined by real-time PCR. The hDEFA/ LL-37 data were normalized to the expression levels of the hACTB internal gene. Relative expression in comparison with the mock controls is shown. Statistical significance: ${ }^{*} \mathrm{p}<0.05{ }^{* *} \mathrm{p}<0.001$.
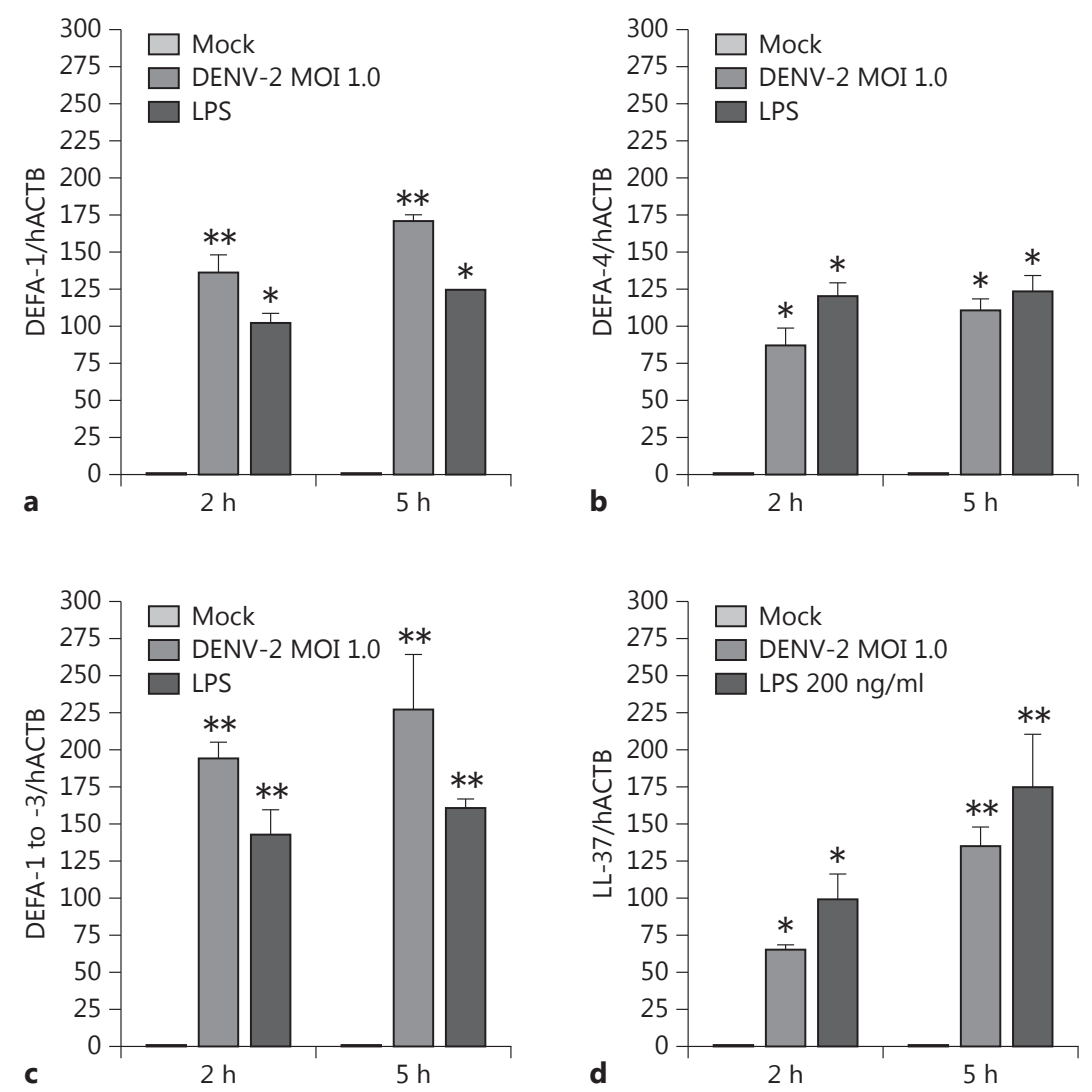

antiviral activity, such as that reported against RSV in vitro [34].

Regarding DENV, information about AMP production in human cells is limited to reports on somatic cells, fibroblasts, and keratinocytes [35, 36]. We analyzed DENV-infected THP-1 macrophage-like cells since these cells represent a study model for human monocytes/macrophages. Monocytes in human blood are not only a central target for DENV, but they also carry out a significant role in the response to DENV infections [37]. We herein show changes in the production of hBD- 1 in THP-1 cells, but were not able to detect alterations in any other $\beta$-defensins in this cell type. We also made an analysis at the mRNA and protein levels for LL-37 cathelicidin in monocytes. One report indicates that cathelicidins mediate vitamin- $\mathrm{D}_{3}$-dependent autophagy in human monocytes/macrophages [38]. Autophagy in monocytic cells is triggered by DENV.
The current results show changes in the production of LL-37 and hBD-1 AMPs by THP-1 cells, but no alterations were detected in any other $\beta$-defensins. THP- 1 cells are differentiated to macrophage-like phenotype with PMA, which could alter results. It is important to point out the reach of this in vitro study, regardless of the value of the THP-1 cells in estimating some aspects of immune response [39]. In the present study, only a screening of mRNA levels and intracellular forms for these AMPs was assessed, but activity of the secreted peptides was not determined. Thus, we consider that future studies are still necessary to support our findings, including in vivo studies.

Surprisingly, we also found increased $\alpha$-defensin levels in the presence of DENV-2. However, it must be considered that only mRNAs (not protein) expression was evaluated in the DENV-2-treated human neutrophils.

The role of these AMPs in immunomodulation may be particularly relevant in effector cells of the immune 
response, such as monocytes/macrophages and neutrophils. For example, depending on the concentrations of HNPs (also known as $\alpha$-defensins) in neutrophils, there is a differential effect of cytokine production in monocytes. HNPs at a concentration of $10^{-8}-10^{-9} \mathrm{M}$ can upregulate the production of TNF- $\alpha$ and IL- $1 \beta$ and downregulate that of IL-10 in monocytes preactivated with either PMA or Staphylococcus aureus. Interestingly, HNPs at a concentration higher than $10^{-4}-10^{-5} \mathrm{M}$ produce a cytotoxic effect on monocytes [40].

One important consideration when evaluating mRNA levels of AMPs is that genes coding for these peptides can be expressed constitutively and also get upregulated during infection. Moreover, gene regulation occurs mostly through signal transduction pathways involving NF- $\mathrm{BB}$ and NF-IL-6 factors [41]. In spite of lacking NF- $\kappa B-$ binding sites, the promoters of defensins (e.g. hBD-1) show consensus-binding sites for IFN- $\gamma$ and NF-IL-6 in their promoter [42]. Thus, a more complete examination on regulation would include other factors such as the cytokines produced during DENV infections.

A very important consideration is that while epithelial cells constitutively express hBD-1, this AMP is upregulated in monocytes by LPS or IFN- $\gamma$. Prior results have clearly shown than hBD-1 has important mechanisms to prevent replication of enveloped viruses in immune cells. In that study, the authors examined the response of hBD1 to HSV-1, influenza, and Sendai viruses in different cell types including monocytes, plasmacytoid dendritic cells, and epithelial cells in vitro and in vivo [43].

The present data indicate that the production of AMPs is an early and rapid response to DENV by macrophagelike THP-1 cells and neutrophils in vitro, after the initial contact of the virus with THP-1 cells and several hours before a robust virus replication in these cells can be observed. We observed the production of LL-37 mRNA from 6 to $48 \mathrm{~h}$, and hBD-1 mRNA from 24 to $72 \mathrm{~h}$ after infection. In THP-1 cells, hBD-1 production declines (at 3 and $5 \mathrm{dpi}$ ), this occurs right after virus antigen is found in a higher percentage of THP-1 cells at $72 \mathrm{~h}$ (fig. 3 and online suppl. fig. 3). Here we found that DENV mediates neutrophils activation by triggering the respiratory burst (online suppl. fig. 5). Neutrophil expression of hDEFA mRNA increased at 2 and $5 \mathrm{~h}$ after challenge with DENV-2.

A more detailed study is necessary to establish AMP protein levels in neutrophils, and to understand the dynamics of DENV-induced AMP production in these cells. For example, HNP levels clearly increase upon contact with the influenza virus and modify the respiratory burst response [44]. The comparison of transcriptional signa-

AMPs in Response to DENV tures in early blood samples in Vietnamese patients revealed that the most significant difference between uncomplicated and dengue shock syndrome cases was the presence of several transcripts associated with neutrophils. The transcript levels, which included those of hDEFAs, did not seem to depend on neutrophil count [45]. This finding questions the central role of neutrophils in dengue pathogenesis since other neutrophil markers, such as elastase, have been found in children with severe dengue manifestations [46].

The current results clearly show that THP-1 macrophage-like cells and neutrophils, soon after making contact with DENV, responded by producing AMPs. AMP production decreased after $72 \mathrm{~h}$ in THP-1 cells. However, an important limitation of the present study is that we examined an in vitro system. Further studies to determine whether or not AMPs have a beneficial effect against DENV infections in vivo are still necessary. It is clear that one mechanism used by pathogens to circumvent AMP activity is the modification of the lipid content of cells or phospholipid levels in cell membranes [28]. A recent report indicated that the lipid content is significantly altered during DENV infections [47]. It is important to establish whether or not these changes are exploited by DENV to circumvent AMP activity and successfully establish an infection.

\section{Acknowledgements}

The authors are grateful to Georgina Filio-Rodríguez and Orestes López-Ortega, former students, and Daniel-Núñez-Avellaneda and Yesica Garcia-Lozano, current students of the Posgrado en Inmunología, for their support at certain points in the development of this investigation. The corresponding author thanks Marguerite Meitzler and Allen Larsen for critical and helpful comments and review of this manuscript. This research project was supported by grants to M.I.S (SIP-20131008, SIP2014542178, and CONACyT-79589) and J.L-H. (SIP-20144218 and CONACyT-180401) from the Secretaría de Investigación y Posgrado del Instituto Politécnico Nacional and the Consejo Nacional de Ciencia y Tecnología. Grant to J.I.C.-S. (PRODEP/SEP 34611549/915056). J.I.C.S., B.E.G.-P., M.A.L.-P., J.L.-H., and M.I.S. are all members of the Sistema Nacional de Investigadores.

Intervirology 2016;59:8-19

DOI: $10.1159 / 000446282$ 


\section{References}

1 Bhatt S, Gething PW, Brady OJ, Messina JP, Farlow AW, Moyes CL, Drake JM, Brownstein JS, Hoen AG, Sankoh O, Myers MF, George DB, Jaenisch T, Wint GR, Simmons CP, Scott TW, Farrar JJ, Hay SI: The global distribution and burden of dengue. Nature 2013;496:504-507.

2 Izadpanah A, Gallo RL: Antimicrobial peptides. J Am Acad Dermatol 2005;52:381-390.

3 Guaní-Guerra E, Santos-Mendoza T, LugoReyes SO, Terán LM: Antimicrobial peptides: general overview and clinical implications in human health and disease. Clin Immunol 2010;135:1-11.

4 Yang D, Chertov O, Oppenheim JJ: Participation of mammalian defensins and cathelicidins in anti-microbial immunity: receptors and activities of human defensins and cathelicidin (LL-37). J Leukoc Biol 2001;69:691697.

5 Kosciuczuk EW, Lisowski P, Jarczak J, Strzałkowska N, Jóźwik A, Horbańczuk J, Krzyzewski J, Zwierzchowski L, Bagnicka E: Cathelicidins: family of antimicrobial peptides. A review. Mol Biol Rep 2013;39:1095710970.

6 Wilson SS, Wiens ME, Smith JG: Antiviral mechanisms of human defensins. J Mol Biol 2013;425:4965-4980.

7 Yang D, Biragyn A, Kwak LW, Oppenheim JJ: Mammalian defensins in immunity: more than just microbicidal. Trends Immunol 2002;23:291-296.

8 Grigat J, Soruri A, Forssmann U, Riggert J, Zwirner J: Chemoattraction of macrophages, T-lymphocytes, and mast cells in evolutionary conserved within the human $\alpha$-defensin family. J Immunol 2007;179:3958-3965.

9 Li D, Zhang L, Yin H, Xu H, Trask JS, Smith DG, Li Y, Yang M, Zhu Q: Evolution of primate $\alpha$ and $\theta$-defensins revealed by analysis of genomes. Mol Biol Rep 2014;41:3859-3866.

10 Ryan LK, Diamond G, Amrute S, Feng Z, Weiberg A, Fitzgerald-Bocarsly P: Detection of $\mathrm{HBD}-1$ peptide in peripheral blood mononuclear cell subpopulations by intracellular flow cytometry. Peptides 2003;24:1785-1794

11 Chertov O, Michiel DF, Xu L, Wang JM, Tani K, Murphy WJ, Longo DL, Taub DD, Oppenheim JJ: Identification of defensin-1, defensin-2 and CAP37/azurocidin as T cell chemoattractant proteins released from interleukin-8-stimulated neutrophils. J Biol Chem 1996;271:2935-2940.

12 Yang D, Chertov O, Bykovskaia SN, Chen Q, Buffo MJ, Shogan J, Anderson M, Schröder JM, Wang JM, Howard OM, Oppenheim JJ: $\beta$-Defensins: linking innate and adaptive immunity through dendritic and T- cells CCR6. Science 1999;286:525-528.

13 Kenshi Y, Richard LG: Antimicrobial peptides in human skin disease. Eur J Dermatol 2008;18:11-21.
14 Treffers C, Chen L, Anderson RC, Yu P: Isolation and characterisation of antimicrobial peptides from deer neutrophils. Int J Antimicrob Agents 2005;26:165-169.

15 Zanneti M: Cathelicidins, multifunctional peptides of the innate immunity. J Leukoc Biol 2004;75:39-48.

16 Tripathi S, Verma A, Crouch E, White M, Harstshorn KL: The human cathelicidin LL37 inhibits influenza A viruses through a mechanism distinct from that of surfactant protein D or defensins. J Gen Virol 2013,94: 40-49.

17 Tolfvenstam T, Lindblom A, Schreiber MJ, Ling L, Chow A, Ooi EE, Hibberd ML: Characterization of early host response in adults with dengue disease. BMC Infect Dis 2011;11: 209.

18 Pan X, Zhou G, Wu J, Bian G, Lu P, Raikhel AS, Xi Z: Wolbachia induces reactive oxygen species (ROS)-dependent activation of the Toll pathway to control dengue virus in the mosquito Aedes aegypti. Proc Natl Acad Sci USA 2012;109:E23-E31.

19 Daigneault M, Preston JA, Marriot HM, Preston JA, Marriot HM, Whyte MKB, Dockrell $\mathrm{DH}$ : The identification of markers of macrophage differentiation in PMA stimulated THP-1 cells and monocyte-derived macrophages. PLoS One 2010;5:e8668.

20 Garza-Hernández JA, Rodríguez-Pérez MA, Salazar MI, Russell TL, Monsuru A, LunaSantillana EJ, Reyes-Villanueva F: Vectorial capacity of Aedes aegypti dengue virus type 2 is reduced with coinfection of Metarhizium anisopliae. PLoS Negl Trop Dis 2013;7:e2013.

21 Summers C, Rankin SM, Condliffe AM, Signh N, Peters AM, Chilvers ER: Neutrophil kinetics in health and disease. Trends Immunol 2010;31:318-324.

22 Choi HS, Kim JW, Cha YN, Kim C: A quantitative nitroblue tetrazolium assay for determining intracellular superoxide anion production in phagocytic cells. J Immunoassay Immunochem 2006;27:31-44.

23 Castañeda-Sánchez JI, García-Pérez BE, Muñoz-Duarte AR, Baltierra-Uribe SL, MejiaLópez H, López-López C, Bautista-De Lucio VM, Robles-Contreras A, Luna-Herrera J: Defensin production by human limbo-corneal fibroblasts infected with mycobacteria. Pathogens 2013;2:13-32.

24 Lehrer RI, Lu W: $\alpha$-Defensins in human innate immunity. Immunol Rev 2012;245:84112.

25 Bastian A, Schäfer H: Human a-defensin 1 (HNP-1) inhibits adenoviral infection in vitro. Regul Pept 2001;101:157-161.

26 Bahar AA, Ren D: Antimicrobial peptides. Pharmaceuticals 2013;6:1543-1575.

27 Peters BM, Shirliff ME, Jabra-Rizk MA: Antimicrobial peptides: primeval molecules or future drugs? PLoS Pathog 2010;6:e1001067.
28 Yeaman MR, Yount NY: Mechanisms of antimicrobial peptide action and resistance. Pharmacol Rev 2003;55:27-55.

29 Haney EF, Hancock RE: Peptide design for antimicrobial and immunomodulatory applications. Biopolymers 2013;100:572-583.

30 Ganz T, Selsted ME, Szklarek D, Harwig SS, Daher K, Bainton DF: Defensins. Natural peptide antibiotics of human neutrophils. J Clin Invest 1985;76:1427-1435.

31 Ganz T: Extracellular release of antimicrobial defensins by human polymorphonuclear leukocytes. Infect Immunol 1987;55:568-571.

32 Jarczak J, Kościuczuk EM, Lisowski O, Strzałkowska N, Jóźwik A, Horbańczuk J, Krzyżewski J, Zwierzchowski L, Bagnicka E: Defensins: natural component of innate immunity. Hum Immunol 2013;74:1069-1079.

33 Guo C-J, Tan N, Song L, Douglas SD, Ho W-Z: Alpha-defensins inhibit HIV infection of macrophages through upregulation of CCchemokines. AIDS 2004;18:1217-1218.

34 Currie SM, Findlay EG, McHugh BJ, Mackel$\operatorname{lar}$ A, Man T, Macmillan D, Wang H, Fitch PM, Schwarze J, Davidson DJ: The human cathelicidin LL-37 has antiviral activity against respiratory syncytial virus. PLoS One 2013;8:e73659.

35 Bustos-Arriaga J, García-Machorro J, LeónJuárez M, García-Cordero J, Santos-Argumedo L, Flores-Romo L, Méndez-Cruz AR, Juárez-Delgado FJ, Cedillo-Barrón L: Activation of the innate immune response against DENV in normal non-transformed human fibroblasts. PLoS Negl Trop Dis 2011;5:e1420.

36 Surasombatpattana P, Hamel R, Patramool S, Lupertlop N, Thomas F, Deprés P, Briant L, Yssel H, Missé D: Dengue virus replication in infected human keratinocytes leads to activation of antiviral innate immune responses. Infect Genet Evol 2011;11:1664-1673.

37 Wong KL, Chen W, Balakrishnan T, Toh YX, Fin K, Wong S: Susceptibility and response of human blood monocyte subsets to primary dengue virus infection. PLoS One 2012; 7: e36435.

38 Yuk JM, Shin DM, Lee HM, Yang CS, Jin HS, Kim KK, Lee ZW, Lee SH, Kim JM, Jo EK: Vitamin $\mathrm{D}_{3}$ induces autophagy in human monocytes/macrophages via cathelicidin. Cell Host Microbe 2009;6:231-243.

39 Chanput W, Mes JJ, Wichers HJ: THP-1 cell line: an in vitro cell model for immune modulation approach. Int Immunopharmacol 2014;23:37-45.

40 Chaly YV, Paleolog EM, Kolesnikova TS, Tikhonov II, Petratchenko EV, Voitenok NN: Neutrophil a-defensin human neutrophil peptide modulates cytokine production in human monocytes and adhesion molecule expression in endothelial cells. Eur Cytokine Netw 2000;11:257-266. 
41 Kaiser V, Diamond G: Expression of mammalian defensin genes. J Leukoc Biol 2000;68: 779-784.

42 O'Neil DA: Regulation of expression of $\beta$-defensins: endogenous enteric peptide antibiotics. Mol Immunol 2003;40:445-450.

43 Tecle T, White MR, Gantz D, Crouch EC, Hartshorn KL: Human defensin increase neutrophil uptake of modify virus-induced respiratory burst response. J Immunol 2007;178: 8046-8052.
44 Ryan LK, Dai J, Yin Z, Megjugorac N, Uhlhorn V, Yim S, Schwarts KD, Abrahams JM, Diamond G, Fitzgerald-Bosarsly P: Modulation of human $\beta$-defensin-1 (hBD-1) in plasmacytoid cells (PDC), monocytes, and epithelial cells by influenza virus, herpes simplex virus, and Sendai virus and its possible role in innate immunity. J Leukoc Biol 2011;90:343356.

45 Hoang LT, Lynn DJ, Henn M, Birren BW, Lennon NJ, Le PT, Duong KTH, Nguyen TTH, Mai LN, Farrar JJ, Hibberd ML, Simmons CP: The early whole blood transcriptional signature of dengue virus and features associated with progression to dengue shock syndrome in Vietnamese children and young adults. J Virol 2010;84:12982-12994.
46 Juffrie M, van der Meer GM, Hack CE, Haasnooty K, Veerman AJP, Thijs LG: Inflammatory mediators in dengue virus infection in children: interleukin-8 and its relationship to neutrophil degranulation. Infect Immun 2000;68:702-707.

47 Cui L, Lee YH, Kumar Y, Xu F, Lu K, Ooi EE Tannenbahum SR, Ong CN: Serum metabolome and lipidome changes in adult patients with primary dengue infection. PLoS Negl Trop Dis 2013;7:e2373. 